\title{
A Comparative Study of Students' Participation in the Management of Nigerian Universities
}

\author{
Ibijola, Elizabeth Yinka (Corresponding Author) \\ Department of Educational Foundations and Management, Ekiti State University, \\ P.M.B. 5363 Ado-Ekiti, Nigeria
}

Tel: 234-806-669-9829Ｅ-mail: ibjemm@yahoo.com

Received: January 3, 2014 Accepted: January 19, 2014 Published: May 5, 2014

doi:10.5296/jet.v1i2.5576 URL: http://dx.doi.org/10.5296/jet.v1i2.5576

\begin{abstract}
This study investigated students' participation in the management of Nigerian Universities. The variables concerned were, level of students' participation in the management of Nigerian Universities, level of organizational effectiveness in the system and the relationship between students' participation in the management of Nigerian Universities and organizational effectiveness.

A descriptive research of survey design was adopted for this study. The sample for the study was made up of 700 subjects, consisting 50 students' union executive members, 200 students randomly selected, 50 top University administrators and 50 lecturers from the Ekiti State University, Ado-Ekiti, Adekunle Ajasin University, Akungba Akoko and Nasarawa State University, Keffi. The samples were selected through stratified and simple random techniques. Data were collected with an instrument titled 'Questionnaire on Students' Participation in the Management of Nigerian Universities (SPMNU).The instrument was validated with reliability co-efficient of 0.93 and subsequently administered on the subjects. Simple percentage was employed to answer the two research questions while the two hypotheses raised were tested using Pearson product moment correlation analysis. The results were held significant at 0.05 levels.
\end{abstract}

Keywords: university system, management, students' participation 


\section{Introduction}

In this work, there are three key words to be addressed. These are; the 'university system', 'management', and 'students' participation'. Universities according to Aluko et al. (1997) were conceptualized as community. It is also described as international community engaged in the search for knowledge and truth (Ede, 2000). Corroborating these views, Olayiwola (1998) argued that a university is more than an institution. According to him it is a collection of people (staff and students). The University either viewed as a community or as an organization, the fact remains that it is made up of individuals and groups with different interest, opinions and ideologies. On this premise, conflict is inevitable, because of the diversity or pluralistic nature of the university as a community.

Management as a concept has also been variously defined by experts, educationists and researchers in the field of management. Ibukun (1997) defined management as a process of delimiting an organization into structural levels, arranging workers and activities into performance units and coordinating resources and production procedures through appropriate leader behaviours to achieve organizational goals. However, the concept of management in education deals with the co-ordination and utilization of resources both human and materials for the accomplishment of educational objectives. As such management of complex community such as the university will definitely require participation through the committee system (Ijomah, 2001).

The use of committee was entrenched in law/act establishing Nigerian Universities as indicated in the University of Ibadan Act of 1962. This Act has to do with the concept of dispersed responsibility because as democratic establishment, universities' decisions must reflect the opinion of a cross section of the staff and students if such decisions are to be acceptable to all concern. This view point was supported by Nwaobasi (1983) and Nwaokolo (1998). This explains why many institutions in the country have established many committees to assist management in arriving at useful and meaningful decisions that could facilitate the proper management and growth of the university system. Hence, Ajayi et al (2005) describes a committee as a device for achieving coordination of activities and sharing information among various departments and divisions of an organization.

However, Ajayi and Ayodele (2002) opined that the effective Universities according to Aluko et al. (1997) were conceptualized as community. It is also described as international community engaged in the search for knowledge and truth (Ede, 2000). Corroborating these views, Olayiwola (1998) argued that a university is more than an institution. Hence, the use of the committee system of management in the management of university system is of great importance and requires that the right person(s) be used. The choice of the right person(s) should depend on their skill, ability and positions in the organization. On this premise, students as an important part of the academic community with their numeric strength deserve full participation in university management. This is desirable, valuable and of paramount importance for the smooth running of the system as it makes the process of democratization very easy and gives room for consultation and joint decision-making and gives room for the concept of dispersed responsibility. Supporting this view, Ikenwe (1998) argued that the 
primary motive of instituting the committee system in institutional governance is to allow for democratization of the decision making process and the need for more broadly based decision making.

'Participation' simply put means to take part, be or become actively involved or share in. Ibijola (2010) noted that the history of students' participation in management of institutions dated back to the $19^{\text {th }}$ century when Bell introduced the method of drilling older children who later taught the young ones. By so doing, the teachers' efforts became multiplied. In a study conducted by Bergan (2005) on students' participation he reported that higher education has been recognized as key to delivering the knowledge requirements for political development. While Lambert (2012) submitted that campus is now the most veritable training ground for future politicians and leaders. Corroborating this view, Akomolafe and Ibijola (2012) also asserted that students' participation allow for development of leadership, and further asserted that there exist a significant relationship between students' participation in university governance and organizational effectiveness.

Ibijola (2010) noted that the rationale for students' participation is desirable, and identified them to include enhance students' commitment and performance and that, most of the problems leading to students' unrest could be resolved if students are allowed their rightful place in university governance. On this premise, committee system of management plays very important roles in the decision making process in the management of universities in Nigeria. The importance of coordination in any organization, most especially in the university system cannot be over emphasized. It is in this vein that the students' representatives should be seen as leaders in their own capacity, knowing fully that they represent the larger percentage of the university community.

The committee system of management adopted by the Nigerian universities is an indicator that issue of effective management in the university system should be seen as a joint responsibility and this allows for the greater participation of more competent staff and student. Ibijola (2010) while citing Chukwudi submitted that students' union government in Nigerian universities offers some ideas for effective administration of universities in Nigeria. An effective management therefore should take advantage of the committee system in ensuring good representation of students on statutory committees of the university. This will invariably assist management in the maintenance of peace and stability within the university system as conflict is inevitable in view of the diversity or plurality in the university system. This is so because organizations consist of individuals with varying needs, interest, values, personalities, opinions and ideologies and as such conflict in organizations can be seen as a by-product of group dynamics. Ibukun (1997) posited that conflict is natural and normal to human organizations.

It is obvious that if the committee system adopted by the Nigerian university system is well managed the current instability within the system would have been averted. A situation where Nigerian universities no longer have a uniform academic calendar calls for concern. It is against this background that the researcher would investigate and compare the level of students' participation in university management and the level of organizational effectiveness 
in Nigerian universities in order to proffer solution to the issue of academic calendar instability.

\section{Statement of the Problem}

It has been perceived for over a decade that Nigerian universities no longer operate a uniform academic calendar that runs from October to September. Every Nigerian university often amends its academic calendar to suit the prevailing situations due to the instability often experience in the system. This definitely has to do with the image of the nation, unlike other countries of the world where admissions for new sessions are advertised at specific period of the year. These problems with its attendant consequences have gone a long way to militate against the quality of Nigerian university education.

The researcher is of the view that if Nigerian university management could make effective use of the committee system of management that encourages democratization of decision making process, the problems resulting into the instability would be a thing of the past in Nigerian university system. It is against this background that the researcher would want to investigate and compare the level of students' participation in university management and the level of organizational effectiveness in Nigerian universities in order to proffer solution to the issue of academic calendar instability.

\section{Research Questions:}

i. What is the level of students' participation in the management of Nigerian universities?

ii. What is the level of organizational effectiveness in the universities?

\subsection{Research Hypotheses:}

i. There is no significant difference among students' participation in university management in AAUA, EKSU and NSUK.

ii. There is no significant difference in the level of organizational effectiveness in the management of AAUA, EKSU and NSUK.

\subsection{Research Method:}

Descriptive research of survey type was employed in this study. The population for this study consisted of all staff and students of the Adekunle Ajasin University, Akungba-Akoko (AAUA), Ekiti State University, Ado-Ekiti (EKSU) and Nasarawa State University, Keffi (NSUK). The sample for this study was made up of 1,050 subjects, consisting of 250 students, 50 non-teaching staff and 50 teaching staff from each of the three universities covered by this study. Stratified random and simple random sampling techniques were used to select the samples. The population was divided into three (3) strata based on the groups within the university, while simple random sampling technique was used to select the samples.

The questionnaire titled Students' Participation in Management of Nigerian Universities (SPMNU) was the instrument used for data collection. The face and content validity of the 
instrument were assessed by two experts in Test and Measurement in the Faculty of Education, Ekiti State University, Ado-Ekiti in order to ensure that the instrument adequately measured the intended content areas of the study. Their observations were used as a guide in reviewing the instrument before administering them to the subjects. The reliability of the instrument was ascertained using the split-half method, i.e. the study utilized the scores from a single test to estimate the consistency of the test items. The split-half method reliability coefficient was corrected to full-length coefficient using the Spearman Brown prophecy formular. The resulting co-efficient was 0.89. Data obtained from the instrument were analyzed using descriptive and inferential statistics. Simple percentage was used to answer the two research questions while the two research hypotheses were tested at 0.05 level of significance using Pearson correlation technique.

\section{Results and Discussion:}

\subsection{Research Question 1:}

What is the level of students' participation in the management of Nigerian Universities?

The findings in respect of question 1 is presented in table 1 and graphically represented in figures 1 below.

Table 1. Level of students' participation in university management.

\begin{tabular}{|c|c|c|c|c|c|c|c|c|}
\hline \multirow{3}{*}{$\begin{array}{l}\text { Level of students' } \\
\text { participation in } \\
\text { university management }\end{array}$} & \multicolumn{6}{|c|}{ Name of university } & \multirow{2}{*}{\multicolumn{2}{|c|}{ Total }} \\
\hline & \multicolumn{2}{|c|}{ AAUA } & \multicolumn{2}{|c|}{ EKSU } & \multicolumn{2}{|c|}{ NSUK } & & \\
\hline & $\mathbf{F}$ & $\%$ & $\mathbf{F}$ & $\%$ & $\mathbf{F}$ & $\%$ & $\mathrm{~F}$ & $\%$ \\
\hline$(41-58.20)$ & 48 & 13.7 & 58 & 15.7 & 67 & 18.6 & 173 & 16.0 \\
\hline Moderate:(58.3-81.57) & 210 & 60.0 & 254 & 68.6 & 265 & 73.6 & 729 & 67.5 \\
\hline$(81.58-100)$ & 92 & 26.3 & 58 & 15.7 & 28 & 7.8 & 178 & 16.5 \\
\hline Total: & 350 & $100.0^{0}$ & 370 & $100.0^{\circ}$ & 360 & $100.0^{\circ}$ & 1080 & $100.0^{\circ} \mathrm{o}$ \\
\hline
\end{tabular}




\section{Macrothink}

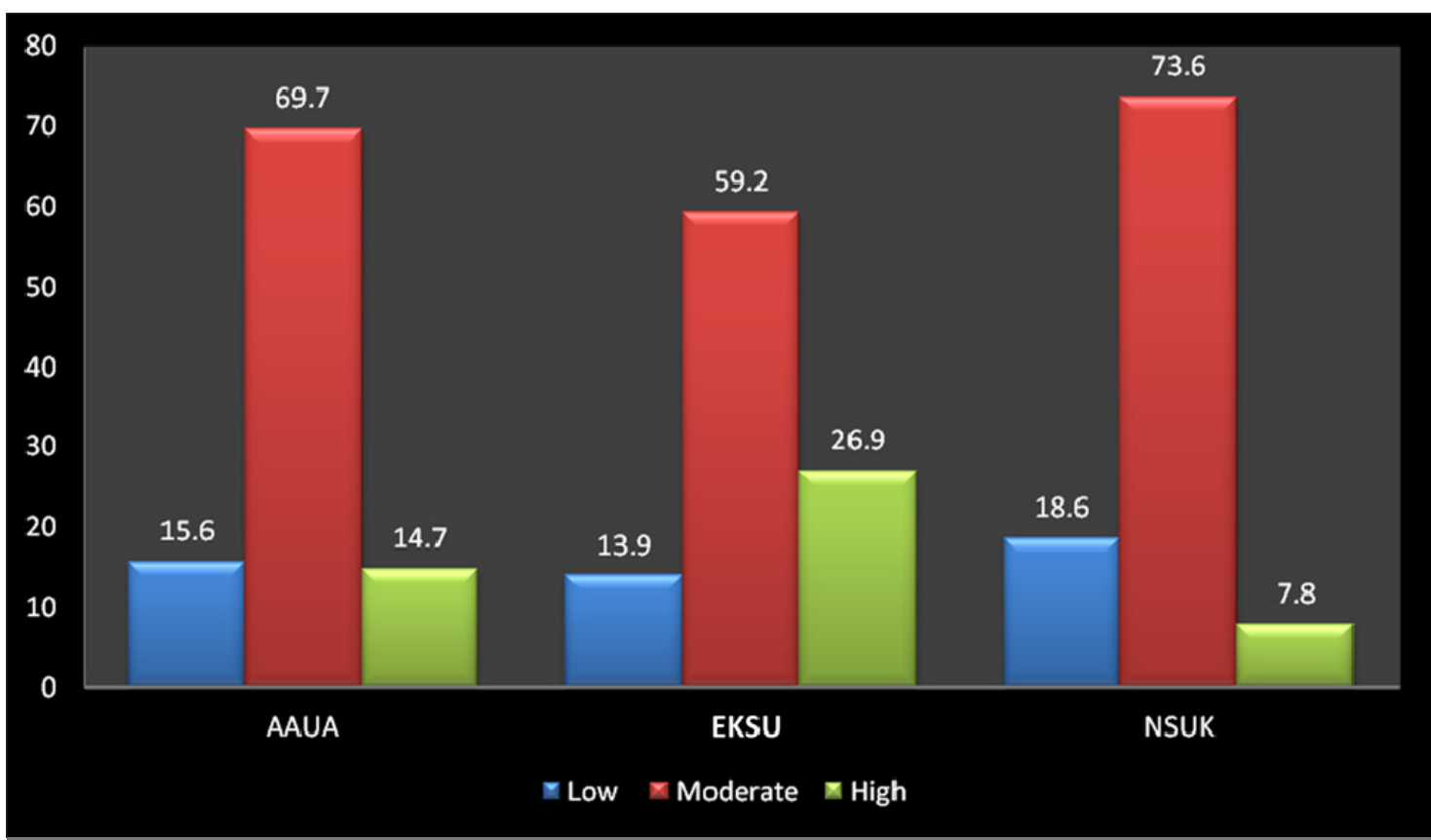

Figure 1. Graphical presentation of the level of students' participation in university management

Table 1 and Figure 1 revealed that the level of students' participation in university management is moderate. Analysis of the result showed that $118(16.9 \%)$ of the respondents agreed to low level of participation while 462 (66\%) and 120 (17.1\%) agrees to "moderate" and "High" levels of participation in university management respectively.

\subsection{Research question 2}

What is the level of organizational effectiveness in the universities?

The summary of the findings in respect of question 2 is shown in Table 2, figures 2.

Table 2. Level of organizational effectiveness in the universities

\begin{tabular}{|c|c|c|c|c|c|c|c|c|}
\hline \multirow{3}{*}{$\begin{array}{l}\text { Level of organizational } \\
\text { effectiveness }\end{array}$} & \multicolumn{6}{|c|}{ Name of university } & & \\
\hline & \multicolumn{2}{|c|}{ AAUA } & \multicolumn{2}{|c|}{ EKSU } & \multicolumn{2}{|c|}{ NSUK } & \multicolumn{2}{|c|}{ Total } \\
\hline & $F$ & $\%$ & $\mathbf{F}$ & $\%$ & $\mathbf{F}$ & $\%$ & & \\
\hline$(33-63.57)$ & 27 & 7.7 & 88 & 23.8 & 69 & 19.3 & 184 & 17.0 \\
\hline Moderate: (63.58-82.88) & 267 & 76.3 & 239 & 64.6 & 261 & 72.5 & 767 & 71.0 \\
\hline$(82.89-100)$ & 58 & 16.0 & 43 & 11.6 & 30 & 8.3 & 129 & 11.9 \\
\hline Total: & 350 & $100.0^{\circ}$ & 370 & $100.0^{\circ}$ & 360 & $100.0^{\circ} \mathrm{B}$ & 1080 & $100.0^{\circ}$ \\
\hline
\end{tabular}




\section{Macrothink}

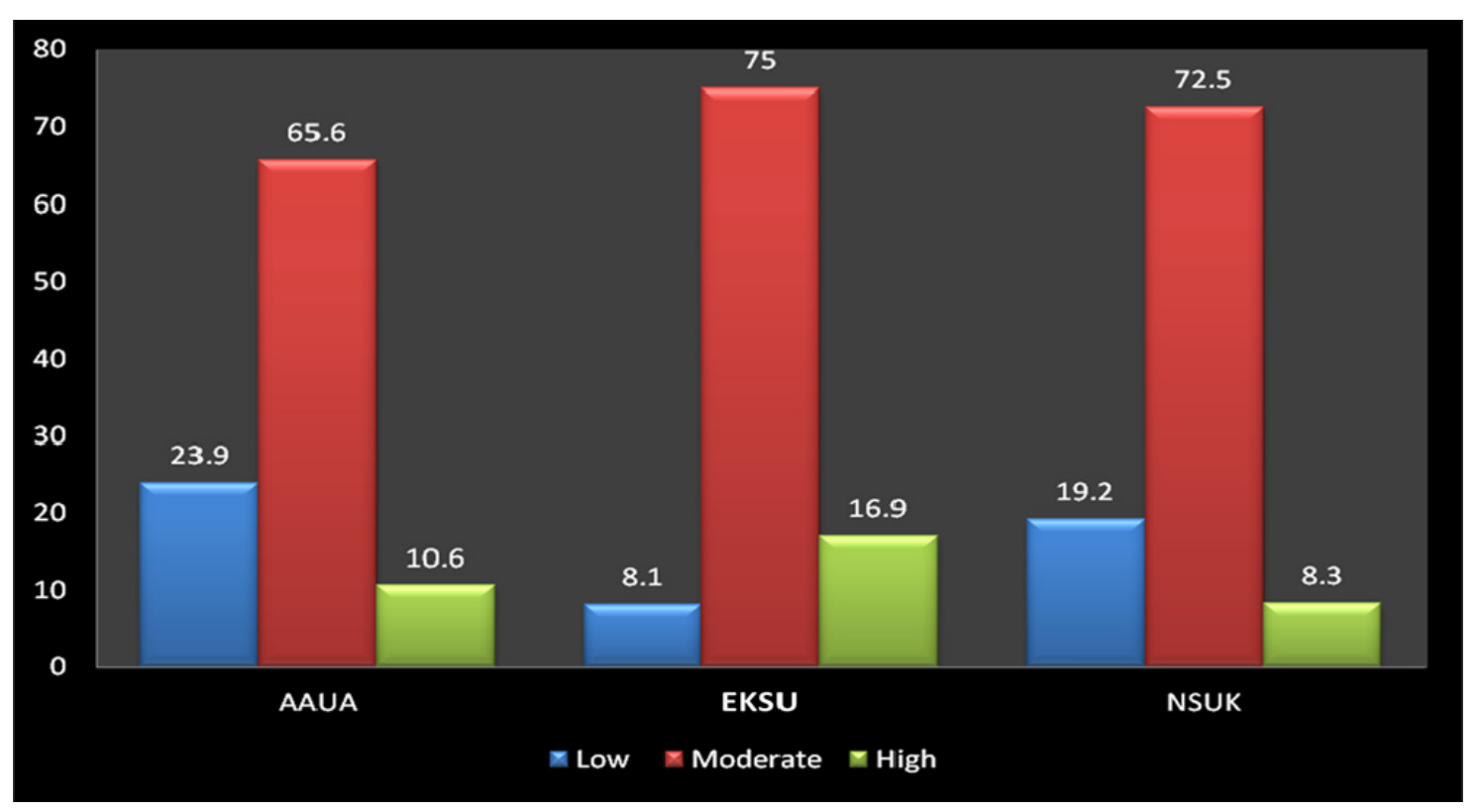

Figure 2. Level of organizational effectiveness in the universities

Table 2 and Figure 2 showed that the level of organizational effectiveness is moderate. The result showed that 131 respondents i.e (18.7\%) adjudged the level of organizational effectiveness as low, while $457(65.3 \%)$ and $112(16.0 \%)$ saw it as "moderate" and "high" respectively. Analysis of the results on university basis was also consistent with the overall result as over $50 \%$ had "moderate" organizational effectiveness in each of the sampled universities.

\section{Testing of Hypotheses}

\subsection{Hypothesis 1}

There is no significant difference among students' participation in university management in AAUA, EKSU and NSUK

Table 3. Oneway ANOVA of students' participation in university management in AAUA, EKSU and NSUK

\begin{tabular}{|c|c|c|c|c|c|}
\hline Source & SS & Df & MS & Fcal & Ftable \\
\hline Between Groups & 5739.235 & 2 & 2869.618 & \multirow{3}{*}{23.411} & \multirow{3}{*}{2.99} \\
\hline Within Group & 132015.90 & 1077 & 122.577 & & \\
\hline Total & 137755.20 & 1079 & & & \\
\hline
\end{tabular}

$\mathrm{P}<0.05$. 


\section{Macrothink}

Table 3 present the students' participation in university management among the selected universities. The result shows that Fcal (23.411) is greater than Ftable (2.99) at 0.05 levels of significance. The null hypothesis is not accepted. Therefore, there is significant difference among students' participation in university management in AAUA, EKSU and NSUK.

In order to determine the source of significant difference, Bcheffe Posthoc test was used. The result is presented in Table 4 .

Table 4. Scheffe Posthoc showing level of students' participation in management of Nigerian universities among selected universities.

\begin{tabular}{|c|c|c|c|c|c|}
\hline Institution & AAUA & EKSU & NSUK & MEAN & N \\
\hline AAUA & & $*$ & $*$ & 68.38 & 360 \\
\hline EKSU & & & $*$ & 71.86 & 360 \\
\hline NSUK & & & & 65.86 & 360 \\
\hline
\end{tabular}

*The mean difference is significant at 0.05 level

Table 4 reveals that the mean difference between AAUA and EKSU, EKSU and NSUK is statistically significant at 0.05 levels. However, the mean difference is significant at 0.05 levels.

\subsection{Hypothesis 2}

There is no significant difference in the level of organizational effectiveness in the management of AAUA, EKSU and NSUK.

Table 5. Oneway ANOVA Showing the Level of Organizational Effectiveness in AAUA, EKSU and NSUK

\begin{tabular}{|l|l|l|l|l|l|}
\hline Source & SS & Df & MS & Feal & Fitable \\
\cline { 1 - 4 } Between Groups & 42.36 .822 & 2 & 2118.411 & & \\
\cline { 1 - 4 } With Groups & 10.5194 .500 & 10.77 & 97.674 & 21.689 & 2.99 \\
\hline Total & 109431.300 & 1079 & & & \\
\hline
\end{tabular}

$P<0.05$.

Table 5 shows that Fcal (21.689) is greater than Ftable (2.99) at 0.05 levels of significance. The null hypothesis is rejected. Therefore, there is significant difference on organizational effectiveness in the management of AAUA, EKSU and NSUK. In order to determine the source of significant difference Scheffe Posthoc Analysis was done as presented in Table 6. 
Table 6. Scheffe Posthoc Analysis of Organizational Effectiveness among Nigerian Universities Management using AAUA, EKSU and NSUK

\begin{tabular}{|l|l|l|l|l|l|}
\hline Institution & AAUA & EKSU & NSUK & MEAN & N \\
\hline AAUA & & $*$ & & 70.48 & 360 \\
\hline EKSU & & & $*$ & 74.0 & 360 \\
\hline NSUK & & & & & 360 \\
\hline
\end{tabular}

*The mean difference is significant at 0.05 level.

Table 6 reveals that the mean difference between AAUA and EKSU, EKSU and NSUK is statistically significant at 0.05 levels. However, there exist no statistical significant difference in the organizational effectiveness of AAUA and NSUK.

\section{Discussion}

The findings of this study revealed a moderate level of students' participation in university management, and a corresponding moderate level of organizational effectiveness. The findings implies that students' participation in university management has being on the average with an average level on organizational effectiveness. This is an indication that in spite of the numeric strength of the students as an important stakeholder in the university community, their level of participation in management is just moderate.

The university system has been conceptualized as an international community engaged in the search for knowledge and truth, and that the management of such complex community will definitely require participation through the committee system, (Ijomah 2001); (Ede, 2000); (Aluko et al., 1997) and (Olayiwola, 1998). Hence, the importance of the committee system of management in institutional governance is to allow for democratizing decision making process, (Ikenwe, 1998). The involvement in decision making within the context of a democratic culture has become necessary to foster conditions of human identification, motivation and loyalty. Akomolafe (2002) argued that participation in decision making process gives the participants greater feeling of self-direction and has a positive relationship with motivation. This finding therefore is an indication that that students are yet to participate fully in university management.

The findings of this study further revealed a significant difference among students' participation in university management in AAUA, EKSU and NSUK. Finding reveals that the mean difference between AAUA and EKSU, EKSU and NSUK is statistically significant at 0.05 level. However, there exist no statistical significant difference in the organizational effectiveness of AAUA and NSUK. However, there is significant difference on organizational effectiveness in the management of AAUA, EKSU and NSUK.

It implies that the three universities differ in their level of organizational effectiveness. This further establishes the significant relationship between students' participation in management and university management effectiveness. The findings agree with Ibijola (2010) who noted that the rationale for students' participation is desirable, and identified them to include 
enhance students' commitment and performance and that, most of the problems leading to students' unrest could be resolved if students are allowed their rightful place in university governance. The significant relationship between student's participation in university management and organizational effectiveness in the universities established in this study agrees with Akomolafe and Ibijola (2012) who submitted that there exist a significant relationship between students' participation in university governance and organizational effectiveness. This implies that the higher the level of students' participation in university management is, the higher the level of management effectiveness will be.

\section{Conclusion}

The findings of this study revealed that student participation in university management is at moderate level. The level of organizational effectiveness established by the study also revealed a moderate level. The study established a significant relationship between students' participation in university management and organizational effectiveness. This implies that organizational effectiveness could be increased to a high level with increase in level of students' participation.

\section{Recommendations}

In view of the findings of the study, students' participation in university management should be increased by allowing more students representation on all statutory university committees. An upward review of the member of student's representatives on each committee is recommended. Management must ensure that students' contribution at meetings count in the decision-making process.

\section{Acknowledgement}

I acknowledge the contributions of my lecturers in the Department of Educational Foundations and Management, Faculty of Education, Ekiti State University in the production of this work. I also acknowledge Mr. Adesina Ogunleye for his effort in typesetting this paper.

\section{References}

Adesanoye, A. P. (1989). A study of Students participation in School Management, A case study of some Secondary Schools in Ikale Local Government Area of Ondo State. An unpublished M.Ed (Educational Administration) Thesis. O.A.U. Ile-Ife.

Ajayi, I. A., \& Ayodele, J. B. (2002). Fundamentals of Educational Management. Ado-Ekiti; Greenline Publishers.

Ajayi, I. A., Ayodele, J. B., \& Ekundayo, H. T. (2005). Fundamentals of Educational Planning. Lagos; Premier Publishers.

Akomolafe, C. O. (2002). Principals' behaviour and staff development in Ekiti State Secondary Schools. Unpublished Ph.D. Thesis.

Akomolafe, C. O., \& Ibijola, E. Y. (2012). Rationale for students' participation in university 
governance in Ekiti and Ondo states, Nigeria. International Journal of Education Administration and Policy Studies, 4(1), 14-18.

Aluko, M., Odugbesan, O., \& Gbadamosi, L. (1997). Business Policy and Strategy. Lagos; Remof Themes Limited (Educational Publishers).

Bergan, S. (2005). Student participation in higher education governance. Retrieved from; http://www.int/t/dg4/highereducation/resource/heseries_en.asp

Ede, S. A. (2000). Educational Administration and Management. Jos, Nigeria: Ibadan: Ichedum Publication Nigeria.

Ibijola, E. Y. (2010). Students' Participation in University Governance and Organizational Effectiveness in Ekiti and Ondo States Nigeria. M.Ed. Thesis Submitted to the Department of Educational Foundations and Management, Ekiti State University, Ado-Ekiti.

Ibukun, W. O. (1997). Educational Management; Theory and practice. Ado-Ekiti; Bangboye and Company Press, Nigeria.

Ijomah, B. I. C. (2001). Strutural dacay and indiscipline in Nigerian institutions; the fault of government. Proceedings of the 12th General Assembly of SSAN 2001 (pp. 182-189).

Ikenwe. (1998). The use of commitee in the state schools. An unpublised Thesis. University of Nsukka.

Lamber, V. (2012). Deception in students politics, The Nation Newspaper of Thursday. April 19, 2012.

Nwaobasi, J. O. (1983). Participative Management in Organization; Theory and Practice. Journal of Nigerian Education research association.

Nwaokolo, P. O. (1998). Democratization of the education System in Nigeria. A paper presented at the Second National Conference on democratization of educational System in Nigeria, held at Federal College of Education, Obudu, Cross River State $22^{\text {nd }}-25^{\text {th }}$ March, 1998.

Olayiwola, O. (1999). Students' Participation in Secondary School Administration in selected Schools of Irewole Local Government Area, Oyo-State. Unpublished M.Ed. Thesis, O.A.U. Ile-Ife.

\section{Copyright Disclaimer}

Copyright reserved by the author(s).

This article is an open-access article distributed under the terms and conditions of the Creative Commons Attribution license (http://creativecommons.org/licenses/by/3.0/). 